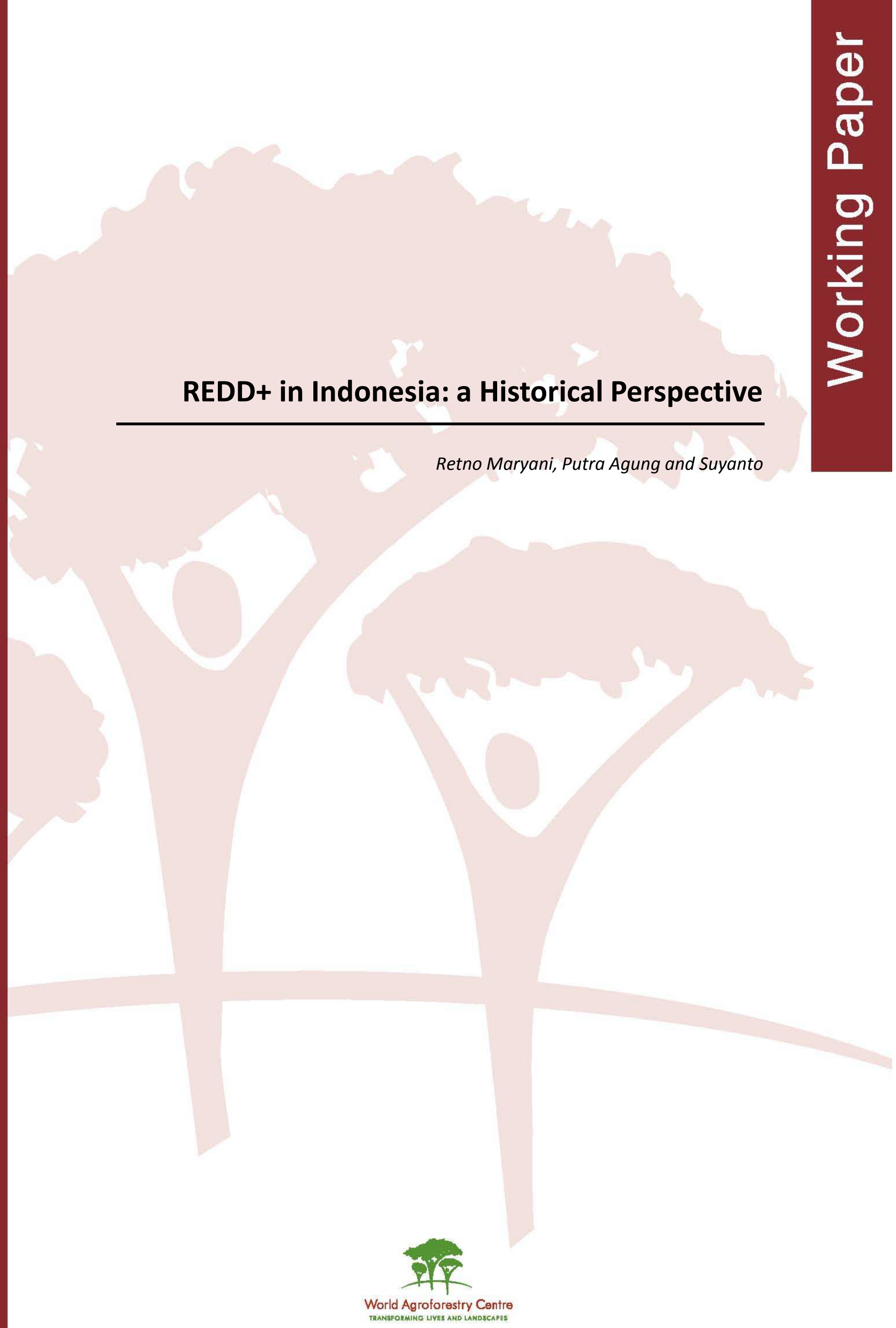





\section{REDD+ in Indonesia: a Historical Perspective}

Retno Maryani, Putra Agung and Suyanto

Working paper 154 


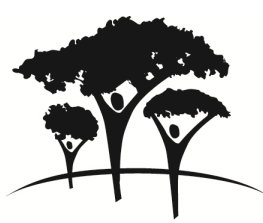

World Agroforestry Centre

TRANSFORMING LIVES AND LANDSCAPES

\section{Correct citation}

Maryani R, Agung P, Suyanto. 2012. REDD+ in Indonesia: a Historical Perspective. Working paper 154. Bogor, Indonesia: World Agroforestry Centre (ICRAF) Southeast Asia Regional Program. DOI: 10.5716/WP12053.PDF. 20p.

Titles in the Working Paper series disseminate interim results from agroforestry research and practices to stimulate feedback from the scientific community. Other publication series from the World Agroforestry Centre include agroforestry perspectives, technical manuals and occasional papers.

World Agroforestry Centre ICRAF Southeast Asia Regional Program Jalan CIFOR, Situ Gede, Sindang Barang Bogor 16115, Jawa Barat [PO Box 161, Bogor 16001]

Indonesia

Tel: +62 2518625415

Fax: +62 2518625416

Email: icraf-indonesia@cgiar.org

http://www.worldagroforestry.org/sea

(C) World Agroforestry Centre 2012

The views expressed in this publication are those of the author(s) and not necessarily those of the World Agroforestry Centre. Articles appearing in this publication may be quoted or reproduced without charge, provided the source is acknowledged. All images remain the sole property of their source and may not be used for any purpose without written permission of the source. 


\section{About the authors}

\section{Retno Maryani}

Retno Maryani is a full time researcher at the Ministry of Forestry since 1988. She works at the Research Center on Forest Policy and Climate Change at Bogor, her major interests on forest governance and forestry institutions. She coordinates research activities at the Ministry of Forestry on management of forest landscape, for the periode of 2010- 2014. She actively involves in discussions, presentations and policy dialogues related with REDD+, and at present she coordinates a collaborative project on bilateral carbon offset scheme. After graduated as a forester from the Gadjah Mada University of Yogyakarta in 1986, she continued her study for Master Degree on Social Forestry from the Wageningen University in 1988. At present, she enrols as a PhD student at the Bogor Agricultural University of IPB.

\section{Putra Agung}

Putra Agung is a researcher under the Economic and Policy Unit (EPU) in ICRAF-SEA Regional Office specializing in Forest Policy and Governance, and engage closely with REDD+ communications and discussions since 2006. Agung obtained his bachelor and master degrees on Forest Management at Bogor Agricultural University.

\section{S Suyanto}

Dr. S Suyanto has more than 15 years experience in natural resource management and institutional analysis. He has worked at the ICRAF-Southeast Asian Regional Research Programme based in Indonesia since 1994, developing a range of skills in socio-economic, natural resource economics, econometrics and institutional analysis. He conducted a study on the evolution of indigenous land tenure and tree resource management in the buffer zone of Kerinci National Seblat Park in Sumatra for his PhD dissertation. In the last five year, He managed several research projects relate on climate change, namely (1). "Efficient and Fair ways of Avoiding Carbon Emissions in Indonesia's Forest Margins: next steps in Negotiation Support Systems" (Ford Foundation Project); (2) "Sustainable livelihood options and carbon rights: a basis for efficient and fair emission reduction in the Central Kalimantan Ex-Mega Rice Project" (AUSAID Project); (3) "Fair, Efficient and Sustainable Emission Reduction from Land Use in Indonesia (FESERLUI)" - (Packard Project); (4) " Accountaibility and local level initiative to reduce emission from deforestation and degradation in Indonesia" (ALLREDDI-EU Project). He is currently leading the economic and policy analysis unit in ICRAF's Indonesia. 


\begin{abstract}
Reducing emissions from deforestation and forest degradation (REDD+), is a policy approach that contains cross-cutting issues and in many developing countries it affects development programs and activities. REDD+ aims to provide positive incentives for those countries who conduct activities for: reducing emissions from deforestation; reducing emissions from forest degradation; preserving carbon stocks; enhancing stocks of forest carbon; and sustaining the management of forests.

Indonesia has adopted policies on REDD+ through several processes of negotiation in international fora, and the adoption is followed by a series of discussions both in the home country and at the regional Asia-Pacific level. The policies are manifested in terms of regulations and the establishment of working groups and new agreements, in addition to demonstration activities supported through bilateral or multilateral collaboration.
\end{abstract}

This paper documents the process of Indonesia's engagement on REDD+ policy through a historical perspective since the 1990's until the present, the institutional and legal framework of REDD+ in Indonesia and the strategy to implement REDD+.

Keywords: REDD+, Policy, Institutional, Indonesia 


\section{Acknowledgements}

This study was part of complementary research projects: the NORAD-funded project,

'Reducing Emissions from All Land Uses (REALU). The authors particularly thanks to working group on climate change at the Ministry of Forestry for intense discussions and shared information that enrich knowledge on the subject Also, thanks to FORDA who gives opportunity for the author to follow on the issue and participate in the discussions on various events on REDD+. 



\section{Contents}

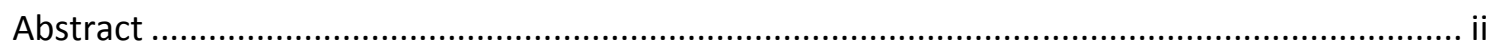

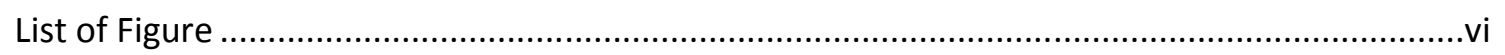

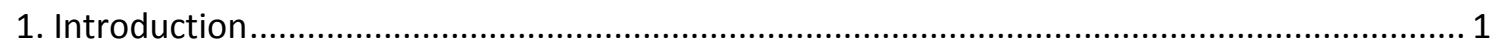

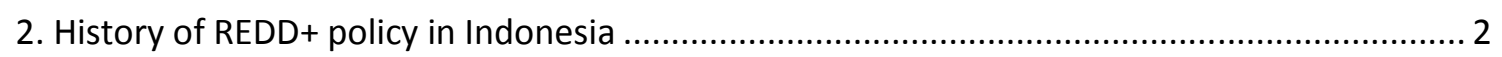

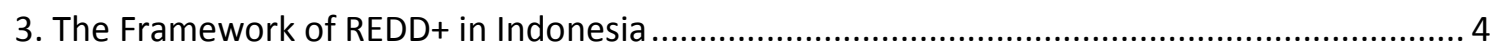

4. Institutional and Legal framework for REDD+ implementation in Indonesia ........................... 6

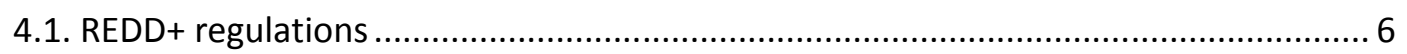

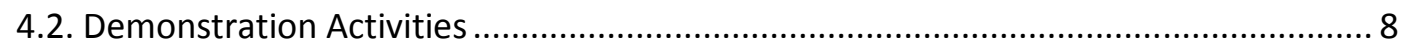

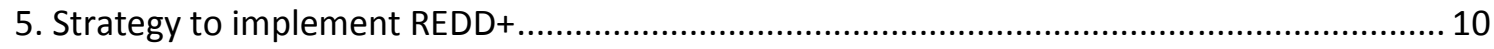

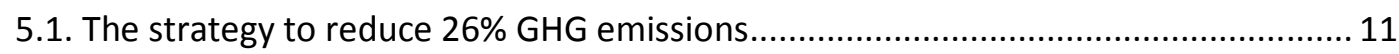

5.2.Letter of Intent/LOI and formation of SatgasREDD ............................................... 12

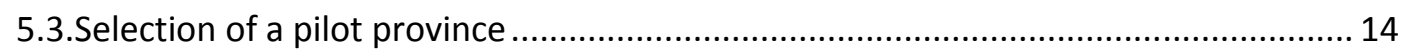

5.4. Presidential Decree on Moratorium of New Concessions on Primary Forest

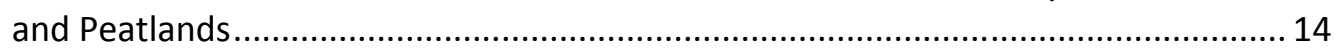

5.5. Developing a Measureable, Reportable and Verifiable System of Emission

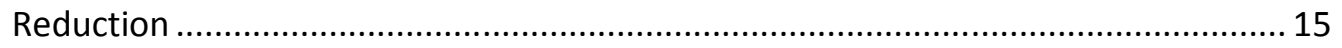

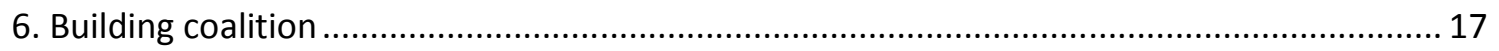

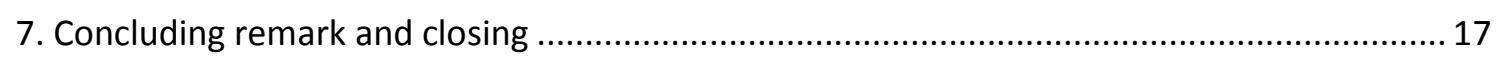

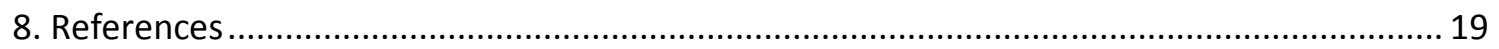




\section{List of Figures}

Figure 1. The Framework of REDD+ in Indonesia. Source: Ministry of Forestry (2008) .........................

Figure 2. Figure. REDD/Readiness Project Sites Distribution. Source: CIFOR and MoF..........................10

Figure 3. The strategy to reduce $26 \%$ GHG emissions. Source: Second National Communication,

The Ministry of Environment 2009 ................................................................................... 11

Figure 4. Indonesia Climate Change Sectoral Roadmap .................................................................. 12 


\section{Introduction}

Indonesia plays an active role in many of the debates concerning the mitigation of climate change by means of reducing emissions that come from deforestation and forest degradation (REDD) because of at least three reasons.

1) The forest area in Indonesia is the third largest in the world after the Democratic Republic of Congo and Brazil.

2) The forest serves as carbon stock and also forestry activities serve as an emission source arising from the conversion of forestland uses into non-forestry uses and from forest fires. Indonesia is a major player, contributing one third of all global emissions and is the largest emitter in the world. Accordingly, the reduction of emissions from this country will have potential impacts to reduce emissions at the global level.

3) The forests are not only the home for communities who depend for their livelihoods on the natural resources stored by the forests, but the resources also provide revenue for the country. The global community supports the policy of the country to reduce its emission level by performing demonstration activities in selected regions. The support is mandated by the Bali Action Plan 2007.

The most recent COP decision held in Cancun, Mexico in 2010 defined the scope of REDD+ and assigned certain instruments for its implementation. The definition of the scope is stated in paragraph 70 of the COP 16 decision that covers five activities: reducing emissions from deforestation, reducing emission from forest degradation, conservation of forest carbon stocks, sustainable management of forests and enhancement of forest carbon stocks. The selection of the REDD++ instruments is stated in paragraph 71 and consists of four components: (i) a national strategy or action plan; (ii) a national reference emission level/reference level (REL/RL), or it may be a combination/aggregate of REL/RL at subnational levels, (iii) a system of forest monitoring that is robust and transparent for the activities of paragraph 70 that include monitoring and reporting the displacement of emissions and (iv) a system for providing information on how safeguards are being addressed and respected throughout the implementation of the activities in paragraph 70 , while respecting the sovereignty of the country.

The nature of REDD+ encompasses cross cutting issues.,In translating the decision of COP-16 into the national context, four major issues challenge Indonesia. The issues are concerned with drivers of deforestation and forest degradation, tenure arrangements, the structure of forest governance and the effective participation of stakeholders with a particular focus on the roles of indigenous people (IP) and the local community.

In this report, we present the approach used by the country to marshal its efforts to meet the challenges by setting regulations, developing entities and implementing supporting activities. The report examines REDD+ policy in the country in terms of its development, its adoption and how it has been mainstreamed into the national policy, and how the policy has 
provided challenges for coordination of its implementation. We begin the report by presenting a brief historical background of REDD+ in Indonesia that serves as the basis to formulate the REDD architecture in the country.

\section{History of REDD+ policy in Indonesia}

As a national policy, REDD+ has been subjected to an evolutionary process. It started from the early 1990's after the Rio Earth Summit in Brazil that provided the declaration on sustainable development and formed the UN Framework Convention on Climate Change (UNFCCC) in 1992. At that time, global experts reached agreement on the level of greenhouse gases (GHG) in the atmosphere that had increased to levels where it was threatening the environment, health, food security and economic activities as well as natural resources and physical infrastructure. The UNFCCC issued a working framework to stabilize the concentration of GHG in order to avoid endangering anthropogenic activities that in turn threatened the climatic system. The initiative to develop the cure for the endangered climate system was endorsed by Indonesia through the issuance of Act no. 6 in 1994 to ratify the UNFCCC initiatives and implement the framework. It was further supplemented by Act no. 23 issued in 1996 that regulates environmental management in the country.

Linked to the UNFCCC, in Japan, the Kyoto Protocol was adopted in 1997 and entered into force in 2005. The Protocol set binding targets for 37 industrialized countries and the European community to reduce GHG emissions. The reduction was set at an average five percent against 1990 levels over the five-year period 2008-2012. The Protocol differs from the Convention as it commits the industrialized countries to undertake emission reduction instead of merely encouragement under the Convention. The Protocol places a heavier burden on the industrialized nations under the principle of 'common but differentiated responsibilities'.

Indonesia ratified the Kyoto Protocol in 2004, and issued Act no. 17 whose intentions among others are to open up new (green) investments from industrialized countries, and to increase the capacity of forests and lands to absorb GHG. Such investments were possible as the Protocol offers an additional means for the industrialized countries to meet their targets by way of three-market based mechanisms, namely Emission Trading or a Carbon Market, a Clean Development Mechanism (CDM) and Joint Implementation. At that time, among these three, CDM was the only mechanism where the developing countries could participate and Indonesia has participated via the manufacturing sector of industry.

The idea of allowing all countries to participate in the reduction of emissions of GHG emerged in Montreal, Canada in 2005. At the 11th session of the UNFCCC, deforestation was raised as an issue to be addressed under the Agenda of 'Reducing Emissions from

Deforestation in Developing Countries'. The issue has been responded to positively by many parties, and that raised the challenge of how national circumstances could be accommodated in a fair and equitable manner considering the way forestry issues were being addressed under the climate convention. 
Following the Montreal decision, Indonesia has hosted communication, coordination and consultation on REDD-related issues. The Indonesia Forest Climate Allience (IFCA) was formed in July for that purposes, in addition to preparing for the next COP-13 to be held in Bali in 2007. IFCA conducted a study that resulted in a framework for reducing emissions from deforestation and forest degradation. The framework served as the basis to take actions in relation to forest policy formulation, the establishment of pilot projects and methodological development through research-related capacities. The study was published as the "Consolidation Report: Reducing Emissions from Deforestation and Forest Degradation in Indonesia", and was issued by the Ministry of Forestry in 2008.

In Bali, COP-13 adopted two decisions, namely the Bali Action Plan as Decision 1/CP13 Para 1 (b)(iii), and Reducing Emissions from Deforestation in Developing Countries: Approaches to Stimulate Action as Decision 2/CP13.

Under Decision1, the concept of REDD+ was identified in the following statement: "Policy approaches and positive incentives on issues relating to reducing emissions from deforestation and forest degradation in developing countries; and the role of conservation, sustainable management of forests and enhancement of forest carbon stocks in developing countries".

Together with Decision2, COP-13 raised five issues which were contentious for many countries. The issues were: (i) scope-what should be included in the definition of REDD, (ii) measurement, reporting and verification, (iii) rights of indigenous people, (iv) financing options and ( $v$ ) institutional arrangements, whether REDD activities were considered as being at the national or project level.

At issue was the scope; parties debated whether it pertains to conservation, sustainable management of forests and the enhancement of carbon stocks in developing countries and furthermore, whether the scope only applies to forestry or all land use and land use change (LULUCF). Also, biodiversity and social benefits are two other key scopes. On rights, it was suggested to include indigenous people and local communities as stakeholders and the extent of their rights in term of their participation, land tenure and distribution of funds. In terms of financing, the debates were concerned about whether REDD should be financed through government via capacity building support, via a fund established under the COP, or via market funding such as allowance auctions, carbon credit market, etc. Regarding the institutional arrangements, concerns arose on whether REDD should be under the Nationally Appropriate Mitigation Action (NAMA), but with limitations for not being eligible to receive funding from market mechanisms. On Monitoring, Reporting and Verification (MRV), concerns arose in addressing issues of setting baselines for the reference level of emissions, addressing leakage and permanence, as well as additionality.

Following the decisions of COP 13 in Bali, Indonesia set a phase-based approach and developed the Strategy of REDD Readiness. Three phases were set from the period of 2007 up to 2012. The first phase has taken place during the period 2007-2008. In this phase, the 
current status of the scientific base and REDD-supported policy were identified. The President formed a National Council on Climate Change the so-called Dewan Nasional Perubahan Iklim (DNPI). Among its tasks, the Council is expected to create consensus around opportunities and challenges related to climate change. It should assist the country in building a cohesive national position in the international negotiations under the Bali Action Plan of the Parties to the UNFCCC.

The Second Phase from 2009 to 2012 was set as the testing period in order to strengthen the scientific base and policy support for REDD implementation. In this phase, the Government of Indonesia (GOI) issued regulations related to REDD, signed agreements with several parties and established a number of pilot projects. In addition, the government also established working groups and task forces in order to facilitate the phasing in of REDD implementation post 2012, which is subject to the decision of forthcoming COP meetings commencing with the one to be held in Durban, South Africa.

The phase-based approach was modified during the process, and it was also adjusted to be in line with the ongoing process of global negotiation and the domestic progress/situation. The approach follows a certain framework and it refers to the REDD architecture as it is presented in the IFCA study.

\section{Framework of REDD+ in Indonesia}

REDD+ policies in Indonesia have a certain framework, although it has never been declared officially nor been formulated in terms of regulations. Benefitting from the IFCA study, prior to the COP-13, REDD+ policies refer to the REDDI architecture produced by that study. The architecture indicates methodological challenges as well as political opportunities to implement REDD in the country. The architecture contains the basic components of REDD+, that include reducing emissions from deforestation, reducing emissions from forest degradation, increasing forest carbon, enhancing the stock of forest carbon and sustainable management of forest. The components were spread over five major activities that are linked to and co-ordinated by working groups, REDD guidelines and an REDD committee as is presented in Figure 1.

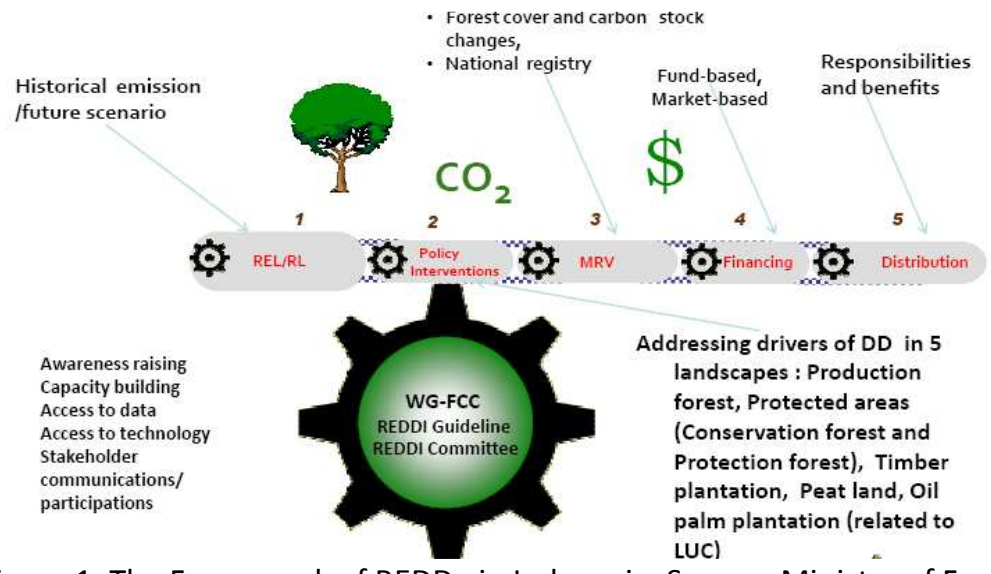

Figure 1. The Framework of REDD+ in Indonesia. Source: Ministry of Forestry (2008) 
The Reference Emission Level/Reference Level (REL/RL) is the baseline against which reductions in emissions are measured. REL/RL is a function of forest area change, combined with the corresponding carbon stocks of the forests being deforested or degraded (IFCA, 2008). REL/RL needs to be set at a certain level or for a certain period, which suggested three approaches. REL could be set by taking the average of past conditions over an agreed time frame (the historical approach). Second, it could also be set by using a modelling approach based on unplanned activities and planned landuse to meet development goals over a specific timeframe. Third, a mixed approach measures emissions from unplanned activities against an REL based on historical unplanned emissions, or an average of historical emissions. This third, mixed approach is said to be the most appropriate for the Indonesian context. However, the approach faces challenges to project deforestation rates, which require more than just technical capacity.

The policy intervention is a component of the strategy, which in the architecture contains actions needed at both the national as well as sub-national levels in order to tackle drivers of deforestation as have been identified by the study of IFCA. The strategy shall be applied to five landscapes consisting of production forests, conservation forests, timber plantation, peatland and oil palm plantation. The last landscape is concerned with activities of land use change.

The monitoring and verification component will measure the success of REDD policies and interventions. This component should be able to translate emission reductions into carbon credits. Monitoring is to be conducted as changes in land use which could be referred from the IPCC guideline set in 2006.

The availability and readiness of markets or funding for forest carbon post emission reduction is clouded by the uncertainty about how a carbon credit for reduced emissions from deforestation will be established. Possible arrangements for the REDD carbon market vary. Fundamental questions yet to be answered include whether the financial mechanism will be based on a fund (fund-based approach) or the creation of a regulated international market for trading carbon credits (market-based approach), and whether credit will be 'fungible' with other types of credits in carbon markets, or whether there will be an exclusive protocol for REDD credits.

The component distribution covers not only benefits but also responsibilities. The debate is concerned with whether the distribution mechanism should be managed at the national, sub-national or project level and more importantly whether any regulations exist to support the selected mechanism.

Beside the five elements of REDDI architecture, other elements play important roles in the process of REDD+ policy formulation and its implementation. These are the Working Group on REDD, Guidelines on REDDI, Committee of REDD+ and other activities related with awareness raising, capacity building and developing access for data and technology, in addition to building up communication among various stakeholders. 


\section{Institutional and legal framework for REDD+ implementation in Indonesia}

A legal framework and institutional supports are needed for the implementation of REDD+ policy in Indonesia. In setting rules and designing strategies for emission reductions, certain key elements are being considered.

The geographical location of the country (located in between the two continents of Asia and Australia) is among the elements, in addition to the characteristics of the country that consists of thousands of islands forming an archipelago. The country had over 225 million people in 2010, distributed unevenly across the islands with Jawa having the highest density with over 600 people living in one square kilometre. The population comes from diverse ethnic groups and they intermingle with facilitation through various development activities. The adoption of a united system of governance has structured the government in a hierarchical order at a national and sub-national level, and the system is in the process of decentralizing its authority from the central to the district level of government. The state controls almost $70 \%$ of forest areas, and the remaining area falls under private forest ownership that has expanded in the Java islands but not on other islands.

Rules for reducing forest carbon emissions, maintaining carbon stocks and increasing its potential shall comply with national regulations besides other legal framework to attain sustainable forest management. The rules have been challenged for their inability to overcome problems in the past.

\subsection{REDD+ regulations}

REDD+ has become a national policy; it is regulated not only by the Ministry of Forestry but also it has involved other ministerial levels and even invited Presidential attention. Various working groups were established and regulations were formed accordingly. At the national level, several sectors or ministries are involved in addressing the issue of climate change.

In 2008, through Presidential Instruction number 46, a National Council for Climate Change was establsihed and named the DNPI. The council acts as the national focal point for global climate negotiations and it has a working group on forestry. Members of the council consist of a number of cabinet ministers and it is led by the President. At the ministerial level, a working group on climate change was formed by the Ministry of Forestry (SK. no.

13/Menhut-II/2009), and it was followed by the establishment of an expert panel on climate change (SK no. 21/Menhut-II/2009).

The Ministry of Forestry regulates mechanisms to reduce emissions that come from forestry activities and implement an REDD Readiness Strategy that has been formulated. The Ministry of Environment (KLH) leads the National Communication to the UNFCCC to report the progress of national policy to reduce GHG , GHG inventory, mitigation and adaptation. A Road Map on mainstreaming climate change issues has been developed for sectors involved 
and it has been submitted to the State Ministry's National Development Plan (BAPPENAS). Furthermore a National Appropriate Mitigation Action (NAMA) has been formulated in addition to the study on the GHG Abatement Cost Curve published by the DNPI.

Three regulations concerning REDD+ were issued by the Ministry of Forestry. The first regulation concerned procedures for establishing demonstration activities on REDD ( $P$ 68/2008). The regulation provides the possibility for an individual actor (investor) and or group of actors as an entity to initiate demonstration activities with approval from the Ministry of Forestry. The entity formulates a proposal on the demonstration activity that contains information on the activity, location, period of collaboration and source of funding. The availability of funding particularly applies for an individual proposal. The proposal shall be approved by the working group tasked by the Ministry, and after approval, it should be implemented first by the developing institutions executing the development activity (DA).

The second regulation of $\mathrm{P} 30 /$ Menhut-II/2009 regulates procedures for REDD. In this regulation, parties who are considered as eligible to conduct REDD are defined and they are named as proponents for REDD. The proponents are in fact rights holders for forest uses as defined in the forestry law issued in 1999. These include the rights of holders to utilize timber products, nontimber products, and the right of a holder to restore an ecosystem. In the regulation, a commission on REDD is appointed to monitor and to recommend qualifications for any proponent and its forest. An independent assessor of LPI (Lembaga Pemantau Independen) was appointed in this regulation to verify the report.

The third regulation is P 36/Menhut-II/2009; it regulates procedures to issue permits on the uses of forest areas under the classification of production and protection forests for the purposes of absorbing and storing forest carbon. This regulation appoints government authorities at the national and sub-national level as legitimate parties to issue permits on forest uses for carbon stock and sequestration. Permits may be granted to right holders on forest uses for areas of production forest and protection forest as defined in the forestry law no. 41/1999. Moreover, this regulation also defines the distribution of benefits and payments that may be shared among government, proponents and community representatives in accordance with the responsibilities of each party.

The three regulations although having been officially declared, have had their effectiveness questioned. As understood, numerous demonstration activities located in various regions hardly make any reference to regulation no. 68/2008. Similarly each demonstration activity hardly ever refers to regulation P 30/2009 on conducting emission reductions. More importantly, P 30/2009 invites lots of criticism concerning the distribution of benefits from REDD, and yet the benefits being promised have not materialized for the community.

On 23 April 2012, the Ministry of Forestry declared another regulation to regulate the implementation of REDD and REDD Readiness that complements the three earlier regulations. In addition to this regulation, some articles were also substituted in regulations no. $68 / 2008$ and no. 30/2009. 
In 2010, the Ministry of Forestry perceived the ongoing process concerning climate change demanded special attention, and therefore organization should be backed up with units dealing with climate change. Through regulation no. 40 issued in 2010, three units dealing with climate change were formed: the Advisor to the Minister on Environment and Climate Change (or Staff Ahli Menteri Lingkungan dan Perubahan Iklim), the Division of Climate Change under the Directorate of Standardization and Environment, and the Research Center on Climate Change and Forest Policy. The three organizations are expected to provide analysis and keen policy recommendations for the implementation of REDD+ in Indonesia.

Beside the REDD Readiness issue, the Indonesian government is also concerned with the reduction of cross-sectoral emissions. This concern was answered by the release of Presidential decree no. 61/2011 on the National Action Plan on Greenhouse Gas Emission Reduction. This regulation itself had to be implemented by the sub-national level of government by the end of 2012 at the latest.

\subsection{Demonstration Activities}

1) REDD+ demonstration activities are another important part of the REDD+ policy development process. Indonesia is undertaking several REDD+ demonstration activities in collaboration with other countries and international agencies, and these will provide important lessons for designing a national REDD+ policy framework. The following are examples of ongoing and proposed demonstration activities:

2) In collaboration with the government of Australia, Indonesia launched the Kalimantan Forest Carbon Partnership in Central Kalimantan. This first demonstration activity project intends to identify drivers of deforestation at the sub-national level, and sets REL/RL at the district level.

3) In collaboration with the government of Germany, the second project of REDD+ has been launched in the East Kalimantan province. Differing from the previous project, this project sets a provincial level as the unit of demonstration activity.

4) Supported by the international organization of The Nature Conservancy, Indonesia launched the Berau Forest Management Programme. The programme uses the sub-national level of Berau district in coordinating an inter-sectoral approach for development activities at the district level, with support from the national government.

5) Supported by the government of South Korea, Indonesia launched a KOICA project in West Nusa Tenggara. The project takes a CDM approach to afforest and reforest degraded land with support from the community.

6) Supported by ITTO, a REDD+ project located inside the National Park of Meru Betiri has been launched in the province of East Java. The project adopts a participatory approach to maintain and enrich carbon stock in a conservation area.

7) In collaboration with UNEP, UNDP, and FAO, Indonesia launched the so-called UNREDD project. The project facilitates communication among stakeholders 
involved in the REDD+ projects, and also builds the capacity of the stakeholders to be ready to implement REDD+. It has selected a single province in Central Sulawesi as the location for REDD demonstration activity.

8) The World Bank supports the readiness process in Indonesia through the program called the Forest Carbon Partnership Facility (FCPF). The program includes analytical works on drivers of deforestation, it enhances communication and outreaches, and its seeks legal opportunities to regulate the payment of REDD+ and the distribution of its benefits. Special attention is given to the roles of indigenous people (IP) and how their interests will be safeguarded in the REDD mechanism. Locations of provinces being proposed to become REDD demonstration activities will include East Jawa, South Sumatera, West Sumatera, North Maluku and Papua.

The status of land tenure and mechanisms to distribute benefits from REDD+ projects are among major issues which have often been debated in support of implementing REDD+. For a certain group, it is feared that REDD+ will enforce the hegemony of the government over natural resources, and also overlook the roles of the community in conserving the resource. Such issues have been debated both at the national and sub-national levels. The emergence of such an issue is expected to open up further discussions and facilitate greater transparency in governing natural resources.

In addition to the above listed activities that have been initiated by the central government, governments at the sub-national or district level have initiated demonstration activities in collaboration with funding parties, particularly from other countries. The Ministry of Forestry classifies the activities as being on a voluntary basis, which have been mapped by CIFOR and the Ministry of Forestry. The map is presented in Figure 2. 


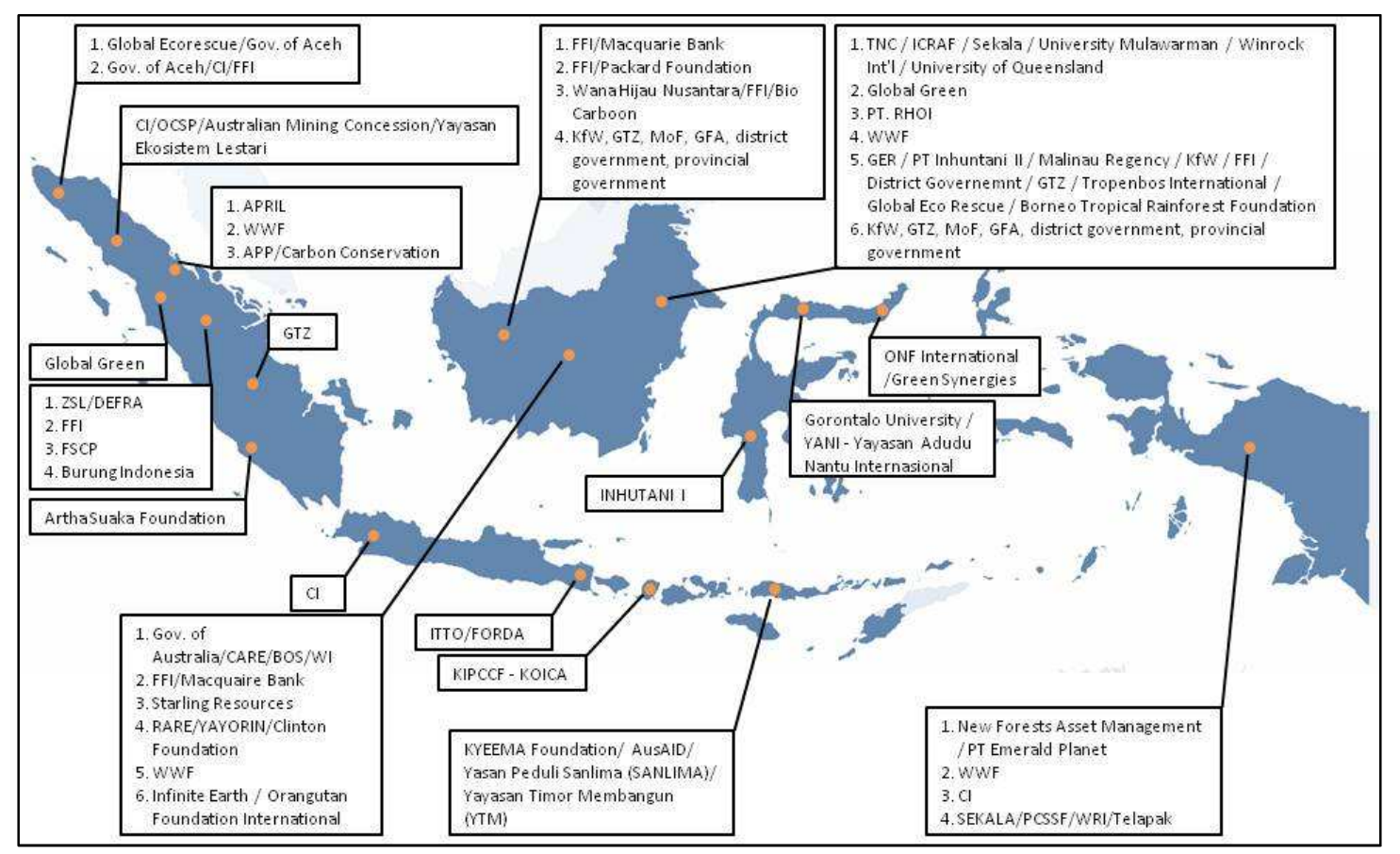

Figure 2.REDD/Readiness Project Sites Distribution. Source: CIFOR and MoF.

Although the exact number has been debated, in total some 44 activities have flourished in Indonesia during the last five years. There is a need to coordinate the activities in particular because they are all concerned with the uses of forestland and with the definition of beneficiaries. Coordination is needed to prevent conflicting claims of use as well as to assure a fair and efficient process for distributing the benefits.

\section{Strategy to implement REDD+}

A National Strategy for the Implementation of REDD+ was developed and published as a draft in September 2010. Formulation of the draft was coordinated by BAPPENAS with support from the Ministry of Forestry under the programme of UNREDD; it involved experts from various disciplines as well as practitioners. The strategy includes among other matters: analysis of drivers of deforestation and forest degradation, elaboration of ongoing progress of REDD+ policies and exploration of possibilities to reform the national development approach to meet the target of REDD+ implementation.

The National Strategy of REDD+ serves as a document to guide national development planning, in line with other national documents such as the mid-term development planning for the five year period from 2010 to 2014, named Rencana Pembangunan Jangka Menengah or RPJM. The document is also embedded in the RKTN, Rencana Kehutanan Tingkat National or the National Forestry Planning for the period 2011 to 2030. To become operational, the National Strategy of REDD+ needs further elaboration into a national action plan that will enable various sectors or ministries and governments at sub-national levels to formulate, implement, monitor and evaluate any programs related to emission reduction from the forestry sector and other sectors concerned with land use. 
In June 2012, the final version of the National Strategy for the Implementation of REDD+ was launched. The document contains the vision for the implementation of REDD+, as well as a set of procedures for REDD+ implementation across Indonesia and also ways in which REDD+ can be synergized with any other national plans/strategies. The National Strategy on REDD+ is a document that should be fused into the sub-national forest sector strategy. But there still remain uncertainty on how to integrate this national/sub-national REDD+ strategy into the national action plan on emission reductions from greenhouse gases which involves cross-sectoral issues.

The National Strategy is based on the national policy to reduce by 26 percent the GHG emission level by the year 2020, and it has gained support from the signing of a memorandum between the governments of Indonesia and Norway which in turn provides momentum to formulate the strategy in an inclusive manner.

Furthermore, the Indonesian government also declared a forest moratorium for two years from 2011 to 2013 through Presidential Instruction no. 10/2011. The aim of this regulation is to delay the issuing of new forest concession permits located in primary forest and also peatland areas.

\subsection{Strategy for a $26 \%$ reduction in GHG emissions}

During the meeting of the group of 20 developed countries (G20) in Pittsburgh, USA in September 2009, the Indonesian President, Susilo Bambang Yudhoyono, declared the country would commit to reduce its emissions from the level of business as usual by a cut of up to $26 \%$ by the year 2020 . At the beginning, the policy invites questions both internationally as well as domestically. In which ways will Indonesia be able to reduce its huge emission level? Communities expressed scepticism of the commitment of Indonesia.

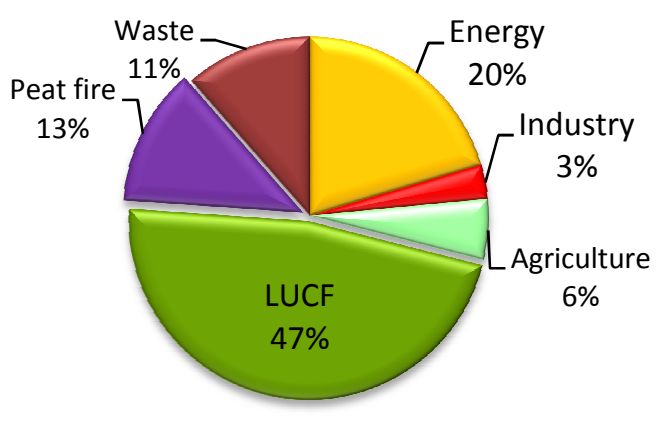

\begin{tabular}{|ll|}
\hline 6. Sector & $\begin{array}{l}7 . \quad \text { Giga } \\
\text { CO2e }\end{array}$ \\
\hline Energy & 280.938 \\
Industry & 42.814 \\
\hline Agriculture & 75.420 \\
LUCF & 649.254 \\
Peat fires & 172.000 \\
Waste & 157.328 \\
\hline TOTAL & 1.377 .754 \\
\hline
\end{tabular}

Figure 3. Strategy to reduce GHG emissions by $26 \%$. Source: Second National Communication, Ministry of Environment 2009

As has been mention earlier, Indonesia is among the countries with the largest GHG emissions in the world. As part of its commitment to reduce its emission levels of GHG, Indonesia has submitted to the UNFCCC its Second National Communication. The report which is submitted by the Ministry on Environment acts as a focal point for the country to present the sourcing of GHG emissions from various development activities. Among the 
sources, land use changes in forestry accounted for $47 \%$ of the total emissions. Together with peat fires, their combined contribution is predicted to be up to $50-55 \%$. Such a level of emission is considered high and threatening to health and food security; furthermore, it may disturb the habitats of many living resources.

Such a high level of emission must be reduced, and efforts to reduce emissions should not be expected only from the forestry sector, as contributions from all sectors are necessary, in particular those sectors using land as their means of development activities. The Indonesian Climate Change Sectoral Roadmap was formulated under the coordination of BAPPENAS. The Roadmap was finalised in March 2010.

The Roadmap identified the cross-cutting issues between the forestry sector and other sectors which need policy attention. These issues are presented in Figure 4.

\begin{tabular}{|l|l|}
\hline Sectors other than forestry: & Forestry Sector: \\
\hline Agriculture & $\begin{array}{l}\text { Policy synchronization needed with a view to expansion of } \\
\text { agricultural land and palm oil plantation as well as other } \\
\text { sources of bio fuel for enhancement of sinks and reducing } \\
\text { emissions from deforestation }\end{array}$ \\
\hline Mining & $\begin{array}{l}\text { Open pit mining in the forest area, mining exploration in } \\
\text { forests }\end{array}$ \\
\hline Energy & $\begin{array}{l}\text { Forest conversion to increase energy alternative supply, } \\
\text { geothermal in forest area and exploration in forests }\end{array}$ \\
\hline $\begin{array}{l}\text { Public Works, Water } \\
\text { Resources }\end{array}$ & $\begin{array}{l}\text { Priority for river catchment area rehabilitation and irrigation } \\
\text { infrastructure development in forest area }\end{array}$ \\
\hline Ocean and Fishery & $\begin{array}{l}\text { Coordination of National park management and mangrove } \\
\text { forest management }\end{array}$ \\
\hline Transportation & Transportation infrastructure development in forest area \\
\hline Industry & $\begin{array}{l}\text { Disease spread indication as the impact of forest and mangrove } \\
\text { forest conversion }\end{array}$ \\
\hline Health &
\end{tabular}

Figure 4. Indonesian Climate Change Sectoral Roadmap

A scenario for reducing emissions by the year 2020 was developed based on practices and guidelines proposed by IPCC.

\subsection{Letter of intent and formation of SatgasREDD}

In May 2010, the governments of Indonesia and Norway signed a Letter of Intent (LOI) in which Norway pledged up to US\$ 1 billion for a program to reduce emissions from deforestation and forest degradation. In return, Indonesia agreed to a number of actions during the preparation phase, which include:

1) To finalize a Strategy of National REDD+

2) To establish a special coordination agency for REDD+. The agency is expected to report directly to the President in order to coordinate efforts pertaining to the implementation of REDD+.

3) To establish an independent institution for MRV

4) To develop an instrument for managing REDD+ funding

5) To select a pilot project for province-wide REDD+ 
The LOI outlines three phases. Phase 1 is called "Preparation", and runs until the end of 2010. Phase 2 is called as a "Transformation" phase that runs from January 2011 until the end of 2013. Phase 3 will start from 2014 and is called "Contribution-for-verified emission reduction".

In order to execute the agreement with Norway, the government of Indonesia has identified nine important actions in forestry that are needed:

1) To establish a special agency that has credibility and transparency, such as that of the Reconstruction and Rehabilitation Agency for Aceh named as Badan Rekonstruksi dan Rehabilitasi (BRR) Aceh;

2) To establish an institution and a system of MRV that has credibility and is internationally recognized;

3) To formulate a National Action Plan for the year 2010-2011;

4) To apply a moratorium for new permits on forest utilization that is valid for a two year period;

5) To conduct a comparative study with the implementation of REDD+ in Brazil;

6) To build communication with business entities;

7) To consult and harmonize the hierarchical relationships among government institutions both at national and sub-national levels;

8) To build mechanisms of consultation with traditional institutions that include the adat institutions;

9) To define institutions that will handle financial management and cooperation between the two countries.

As the first step for implementing the LOI, the Government of Indonesia formulated three activities which were to be finished before the end of the preparation phase (end of 2010). Each activity had a coordinating agency:

1) BAPPENAS coordinated formulation and finalization of the REDD+ strategy

2) UKP4 coordinated the institutional arrangements for the development and implementation of REDD+

3) CIFOR coordinated the institutional arrangements for an independent MRV institution that included the MRV strategy and a framework.

In order to strengthen the establishment of institutions for REDD+, in 2010, the President issued a decree to establish a task force to prepare an institutional setting for REDD+ (Satgas $R E D D+)$ starting from December 2010 up to June 2011. The Satgas was headed by Dr. Kuntoro Mangkusubroto, who is also the head of UKP4 that has a primary task to monitor the progress of each Ministerial agency in implementing its development plan. Members of the Satgas were representatives from different ministries, including the Ministry of Finance, Ministry of Forestry, the National Agrarian Agency, DNPI, Ministry of Environment and academia as well as representative from the cabinet secretariat. 
The Satgas was supported by six technical teams that each had a different focus. They were: for the REDD+ Strategy, for REDD+ institutions and their governance, for financing instruments, forMRV and the moratorium, for multistakeholder processes and for selection of a pilot province for the implementation of REDD+.

\subsection{Selection of a pilot province}

In order to meet the $26 \%$ emission reduction target based on the business as usual level by the year 2020, the government has decided to conduct this emission reduction at the province level. Of this total, $14 \%$ would have to come from reducing emissions from REDD+ . The LOI with Norway facilitates the implementation by selecting a single province as a pilot project. The selection involves multi-stakeholder processes that include representatives from government at the national and sub-national levels, academia and research institutions, representatives from business entities and NGOs. The processes include developing criteria and indicators and a scoring system, developing mechanisms for decision making and for the communication of REDD+ project activities using the approach of free prior informed consent (FPIC). The selection process decided that Central Kalimantan would be the pilot province for REDD+ implementation.

\subsection{Presidential decree on moratorium on new concessions on primary forest and peatlands}

A part of the strategy to eliminate emissions from deforestation and forest degradation is to stop the conversion of forests into other land uses, which is also part of the agreement with Norway. A major component involves the suspension of new concessions for conversion of primary forest and peatland area. The President accordingly issued a decree in May 2011, which is known as Inpres 10/2011 on the forest moratorium.

The decree forbids new concessions for primary forests and peatlands for a two year period. It applies to all forest functions including conservation, protection and production forest. There some exemptions and these include new concessions awaiting approval from the Ministry of Forestry, and other programs which are considered essential for national development such as the development of the energy program by utilizing geothermal energy, oil and gas, and electricity and the development of food crops by expanding sugarcane and rice plantations. In forestry, exemptions apply to existing concessions which are under the extension process and to concessions for ecosystem restoration.

The moratorium is considered a controversial policy, as it threatens palm oil investment which for Indonesia is a promising sector providing job opportunities and boosting economic growth in remote regions. Strong lobbying from the forest and tree crop plantation industry has argued that the economy will be harmed if business as usual is interrupted. However, the forestry sector argues there are still over 30 million hectares of forestlands which are covered by secondary vegetation available for new investment. The policy forbids clearing of 
some 64.2 million hectares of forest area which are covered by primary vegetation in addition to 24.5 million hectares of forest growth on peatland areas.

Discussions concerning the implementation of the forest policy moratorium may not be separated from what has been perceived or understood by people with terms such as 'forests and primary forests' or the term 'peatlands and forest peatlands'. The discussions were rooted in how far conservation purposes allow for utilization activities. An example that has been provided by the regulation on peatland of PP no. 26/2008 that provides for the possibility to utilize peatlands below three metres depth. Moreover, the Ministry of Agriculture has issued a guideline for palm oil cultivation on peatlands through regulation no. $14 / 2009$.

In general, there are three key issues concerning the policy that need to be resolved:

1) Scope of the area to be covered by the policy. If the policy is limited to forest areas, one third of the current emission from change in woody vegetation will remain unaccounted for, since the institutional mandates and types of permits issued by the government differ between forestland and other land uses (Serge Wich, Lian Pin Koh and Meine van Noordwijk in the Jakarta Post 21 February 2011).

2) Sites where the moratorium is to be applied. The Ministry proposes a moratorium limited to protecting primary forests, and defines these as "natural forests untouched by cultivation or silvicultural systems applied in forestry". Part of Indonesia's logged-over (secondary) forest still has high carbon stocks and is important for biodiversity conservation. Clarification on sites was presented in a moratorium map, that is to be updated every six months.

3) Status of peatlands whether under the forest area or outside the area. Peatlands occur both within and outside of the forest estate and are a source of emissions whether forested or not. The Ministry of Forestry draft excluded any new concessions on peatlands deeper than three meters - which in fact already are illegal. A challenge is to increase the accuracy of existing maps concerning peatdepth.

Other discussion raised from this moratorium decree has been on the implementation monitoring and supervision. Many stakeholders believe that it is hard to fully monitor and to fully supervise the implementation of this regulation considering the lack of coordination among government institutions. This regulation mandated a six-monthly update of the moratorium map. To date, there have been two updates of the moratorium map since the regulation was issued, and now the third update is being discussed.

\subsection{Developing a measureable, reportable and verifiable system of emission reduction}

A system of measuring, reporting and verifying (MRV) emission reduction needs to be developed. The system needs to be transparent, internationally-accepted and standardized 
for independent bodies to conduct verification. A system of monitoring for Indonesia is still to be designed to facilitate reporting verification. Guidelines for monitoring are indicated in COP decisions (2/CP13 and 4/CP15) that require the use of a combination of remote sensing and ground-based forest carbon inventory approaches for estimating forest-related GHG emissions by sources and removals by sinks, forest carbon stocks and forest area changes. Guidelines and modalities for reporting and verification are still to be developed and agreed by COP.

The Government of Indonesia (GOI) has put considerable effort into setting up a transparent and internationally-accepted measuring, reporting and verification system. The agreement between GOI and Norway shows a significant investment to achieve this goal that has been supported by the development of institutions and mechanisms to establish a robust MRV system through the establishment of interrelated institutions, finances, REDD+ and MRV.

Two regulations were issued through Presidential decrees. These are the Presidential Decree of Inpres no. 61/2011 on the National Action Plan for GHG Reduction, and the Inpres no. $71 / 2011$ concerning the National Action Plan for GHG Inventory. Implementation of the decrees was executed by BAPPENAS who coordinates the formulation of the Provincial Action Plan for GHG Reduction (Rencana Aksi Daerah/RAD GRK).

For a successful implementation of MRV, a number of challenges need to be clarified. Dialogues on various key elements of MRV which are to be built need to be framed accordingly. These include policy design, data acquisition and management, technology and technical capacities, in addition to the institutional mechanism among key agencies operating at different level of governance. The agreement with Norway pointed out the need to establish a credible and reliable institutional body for MRV at the national level (Lembaga MRV). Such an institution is still being developed. Within the Ministry of Forestry, the Directorate General of Forest Planning potentially has that capacity, as data acquisition and processing concerning forest landuse changes are among its main activities. Some adjustments may need to be made to convert the existing data of standing stock timber into wooden biomass and then to translate it further into forest carbon stocks. However, as reductions of emissions from forestry activities involve active roles by other sectors, it is questionable therefore if the Ministry of Forestry alone should shoulder the tasks for institutionalising the system of MRV for the whole country.

Implementation of the system of REDD+ and MRV needs to be tested in Central Kalimantan as the province was selected to become a pilot project for implementing the agreement between GOI and Norway. The pilot project is coordinated by the Task Force of REDD+. Meanwhile, the Ministry of Forestry has formulated a Road Map of Forestry MRV. The Road Map identifies some activities to support the implementation of MRV. These include activities to re-design field data acquisition for National Forest Inventory both at the national and sub-national levels, to compare different methods for setting REL/RL that have been used by different demonstration activities and to develop allometric equations for the prominent species or vegetation types, as well as to re-adjust the existing classification of 
forestland uses (source: paper presented by Director of Forest Resources Inventory and Monitoring in Tokyo, 7 February 2012). The development of an institutional system for MRV has been supported by CIFOR.

\section{Building coalition}

Processes for implementing REDD+ and preparing policies for its implementation have created a new arena for building coalitions between various actors and institutions at the global, regional and also local level. At the level of countries where tropical forests are situated, a Coalition for Rain Forest Nations has been formed to strengthen the positions of member countries in negotiating their interests at global meetings. Indonesia, together with Brazil, Guatemala, Mexico, Cameroon, Malaysia and Thailand has established a Forest Eleven (F-11) forum. The forum aims to establish platforms of dialogue and to share experiences among members countries in preparing the implementation of REDD+. At the level of ASEAN countries, a forum of ASEAN Regional Knowledge Networks has been established to exchange ideas and share experiences.

One of the important issue concerning coalitions is the issue of indigenous people. This is among the important issues for Indonesia consideration given the country voted for the adoption of the United Nations Declaration on Rights of Indigenous People (UNDRIP) at the UN General Assembly on 13 September 2007. For Indonesia, the term indigenous people (IP) has usually referred to ethnic groups in the country covering over 1000 ethnic groups living on thousand islands in Indonesia. REDD+ policy should be safeguarded to prevent IP and other groups from being excluded from the potential benefits of REDD+ and thus not having their voices heard.

Methods to ensure potential REDD+ benefits will flow to IP and other customary groups were discussed at several events. Several approaches are already available and are being tested for their application in Indonesia. Among the approaches are free prior and informed consent (FPIC), Rights Based Approach, HumaWin, Information System for Safeguards Policy, and HCVF. Each approach has its advantages and limitations, and for the UNREDD program, FPIC has been promoted with certain conditions.

\section{Concluding remarks}

There are several policies at the national level issued to address the challenge of reducing greenhouse gas emissions in Indonesia. REDD+ implementation is regulated with at least four policies-Ministry of Forestry regulation numbers 68/2008, 30/2011, 36/2011 and now the latest being regulation number 20/2012. Overall, the strategy to implement REDD+ in Indonesia has been stated in the National Strategy on REDD+ Implementation. Based on these policies, the implementation of REDD+ strategies also has to be developed at the subnational level through the document called the Provincial Strategy and Action Plan on REDD+ (SRAP REDD+). 
From this perspective, the question arises as to how implementation of REDD+ can be synergized with the National Appropriate Mitigation Action (NAMA) plan that produced the National Action Plan on Green House Gases Emission Reduction (RAN-GRK). REDD+ can be counted as a part of NAMA by the forestry sector, but it still needs strong coordination and communication among government institutions.

Furthermore, there is also a high expectation that REDD+ implementation could be used as a vehicle to promote forest governance reform in Indonesia. REDD+ should be taken into account as an added value for good forest management practices by fully implementing the REDD+ requirements such as good planning and coordination, clear and accountable policy and a legal institutional framework, successful demonstration activities, accountable MRV system and a transparent, efficient and fair benefit sharing mechanism. 


\section{References}

Kemenhut. 2012. Peta Proyek Percontohan REDD di Indonesia. http://www.reddindonesia.org/index.php?option=com_content\&view=article\&id=205\&ltemid=57. Accessed: September 14, 2012.

Sekretariat UNFCCC 2009 : Dec. 4/CP.15 (Methodological guidance for activities relating to reducing emissions from deforestation and forest degradation and the role of conservation, sustainable management of forests and enhancement of forest carbon stocks in developing countries)

Ministry of Forestry. 2008. Consolidation Report Reducing Emissions from Deforestration and Forest Degradation in Indonesia.

Ministry of Environment. 2009. Second National Communication Indonesia under the UNFCCC.

Masripatin N. 2011. Penerjemahan REDD+ safeguard pada keputusan COP-16 ke dalam konteks Indonesia. Makalah workshop penerjemahan keputusan COP-16 Tentang "REDD+ SAFEGUARDS" dalam rangka pengembangan Sistem Informasi tentang pelaksanaan SAFEGUARDS REDD+ di Indonesia. Jakarta, 21 Maret 2011.

Sekretariat UNFCCC 2009 : Dec. 4/CP.15 (Methodological guidance for activities relating to reducing emissions from deforestation and forest degradation and the role of conservation, sustainable management of forest and enhancement of forest carbon stocks in developing countries).

Satuan Tugas Persiapan Kelembagaan REDD+ 2012. Strategi Nasional REDD+.

Wich S, Koh LP and Van Noordwijk M. Jakarta Post February $21^{\text {st }} 2011$. The Indonesia deforestation moratorium : the devil is in the details. 



\section{WORKING PAPERS IN THIS SERIES}

\section{5}

1. Agroforestry in the drylands of eastern Africa: a call to action

2. Biodiversity conservation through agroforestry: managing tree species diversity within a network of community-based, nongovernmental, governmental and research organizations in western Kenya.

3. Invasion of prosopis juliflora and local livelihoods: Case study from the Lake Baringo area of Kenya

4. Leadership for change in farmers organizations: Training report: Ridar Hotel, Kampala, 29th March to 2nd April 2005.

5. Domestication des espèces agroforestières au Sahel: situation actuelle et perspectives

6. Relevé des données de biodiversité ligneuse: Manuel du projet biodiversité des parcs agroforestiers au Sahel

7. Improved land management in the Lake Victoria Basin: TransVic Project's draft report.

8. Livelihood capital, strategies and outcomes in the Taita hills of Kenya

9. Les espèces ligneuses et leurs usages: Les préférences des paysans dans le Cercle de Ségou, au Mali

10. La biodiversité des espèces ligneuses: Diversité arborée et unités de gestion du terroir dans le Cercle de Ségou, au Mali

\section{6}

11. Bird diversity and land use on the slopes of Mt. Kilimanjaro and the adjacent plains, Tanzania

12. Water, women and local social organization in the Western Kenya Highlands

13. Highlights of ongoing research of the World Agroforestry Centre in Indonesia

14. Prospects of adoption of tree-based systems in a rural landscape and its likely impacts on carbon stocks and farmers' welfare: The FALLOW Model Application in Muara Sungkai, Lampung, Sumatra, in a 'Clean Development Mechanism' context

15. Equipping integrated natural resource managers for healthy Agroforestry landscapes.

17. Agro-biodiversity and CGIAR tree and forest science: approaches and examples from Sumatra.

18. Improving land management in eastern and southern Africa: A review of policies.

19. Farm and household economic study of Kecamatan Nanggung, Kabupaten Bogor, Indonesia: A socio-economic base line study of Agroforestry innovations and livelihood enhancement.

20. Lessons from eastern Africa's unsustainable charcoal business.

21. Evolution of RELMA's approaches to land management: Lessons from two decades of research and development in eastern and southern Africa

22. Participatory watershed management: Lessons from RELMA's work with farmers in eastern Africa.

23. Strengthening farmers' organizations: The experience of RELMA and ULAMP.

24. Promoting rainwater harvesting in eastern and southern Africa.

25. The role of livestock in integrated land management.

26. Status of carbon sequestration projects in Africa: Potential benefits and challenges to scaling up.

27. Social and Environmental Trade-Offs in Tree Species Selection: A Methodology for Identifying Niche Incompatibilities in Agroforestry [Appears as AHI Working Paper no. 9]

28. Managing tradeoffs in agroforestry: From conflict to collaboration in natural resource management. [Appears as AHI Working Paper no. 10]

29. Essai d'analyse de la prise en compte des systemes agroforestiers pa les legislations forestieres au Sahel: Cas du Burkina Faso, du Mali, du Niger et du Senegal.

30. Etat de la recherche agroforestière au Rwanda etude bibliographique, période 1987-2003

\section{7}

31. Science and technological innovations for improving soil fertility and management in Africa: A report for NEPAD's Science and Technology Forum.

32. Compensation and rewards for environmental services.

33. Latin American regional workshop report compensation. 
34. Asia regional workshop on compensation ecosystem services.

35. Report of African regional workshop on compensation ecosystem services.

36. Exploring the inter-linkages among and between compensation and rewards for ecosystem services CRES and human well-being

37. Criteria and indicators for environmental service compensation and reward mechanisms: realistic, voluntary, conditional and pro-poor

38. The conditions for effective mechanisms of compensation and rewards for environmental services.

39. Organization and governance for fostering Pro-Poor Compensation for Environmental Services.

40. How important are different types of compensation and reward mechanisms shaping poverty and ecosystem services across Africa, Asia \& Latin America over the Next two decades?

41. Risk mitigation in contract farming: The case of poultry, cotton, woodfuel and cereals in East Africa.

42. The RELMA savings and credit experiences: Sowing the seed of sustainability

43. Yatich J., Policy and institutional context for NRM in Kenya: Challenges and opportunities for Landcare.

44. Nina-Nina Adoung Nasional di So! Field test of rapid land tenure assessment (RATA) in the Batang Toru Watershed, North Sumatera.

45. Is Hutan Tanaman Rakyat a new paradigm in community based tree planting in Indonesia?

46. Socio-Economic aspects of brackish water aquaculture (Tambak) production in Nanggroe Aceh Darrusalam.

47. Farmer livelihoods in the humid forest and moist savannah zones of Cameroon.

48. Domestication, genre et vulnérabilité : Participation des femmes, des Jeunes et des catégories les plus pauvres à la domestication des arbres agroforestiers au Cameroun.

49. Land tenure and management in the districts around Mt Elgon: An assessment presented to the Mt Elgon ecosystem conservation programme.

50. The production and marketing of leaf meal from fodder shrubs in Tanga, Tanzania: A pro-poor enterprise for improving livestock productivity.

51. Buyers Perspective on Environmental Services (ES) and Commoditization as an approach to liberate ES markets in the Philippines.

52. Towards Towards community-driven conservation in southwest China: Reconciling state and local perceptions.

53. Biofuels in China: An Analysis of the Opportunities and Challenges of Jatropha curcas in Southwest China.

54. Jatropha curcas biodiesel production in Kenya: Economics and potential value chain development for smallholder farmers

55. Livelihoods and Forest Resources in Aceh and Nias for a Sustainable Forest Resource Management and Economic Progress

56. Agroforestry on the interface of Orangutan Conservation and Sustainable Livelihoods in Batang Toru, North Sumatra.

57. Assessing Hydrological Situation of Kapuas Hulu Basin, Kapuas Hulu Regency, West Kalimantan.

58. Assessing the Hydrological Situation of Talau Watershed, Belu Regency, East Nusa Tenggara.

59. Kajian Kondisi Hidrologis DAS Talau, Kabupaten Belu, Nusa Tenggara Timur.

60. Kajian Kondisi Hidrologis DAS Kapuas Hulu, Kabupaten Kapuas Hulu, Kalimantan Barat.

61. Lessons learned from community capacity building activities to support agroforest as sustainable economic alternatives in Batang Toru orang utan habitat conservation program (Martini, Endri et al.)

62. Mainstreaming Climate Change in the Philippines.

63. A Conjoint Analysis of Farmer Preferences for Community Forestry Contracts in the Sumber Jaya Watershed, Indonesia.

64. The highlands: a shared water tower in a changing climate and changing Asia

65. Eco-Certification: Can It Deliver Conservation and Development in the Tropics.

66. Designing ecological and biodiversity sampling strategies. Towards mainstreaming climate change in grassland management.

67. Towards mainstreaming climate change in grassland management policies and practices on the Tibetan Plateau 
68. An Assessment of the Potential for Carbon Finance in Rangelands

69 ECA Trade-offs Among Ecosystem Services in the Lake Victoria Basin.

69. The last remnants of mega biodiversity in West Java and Banten: an in-depth exploration of RaTA (Rapid Land Tenure Assessment) in Mount Halimun-Salak National Park Indonesia

70. Le business plan d'une petite entreprise rurale de production et de commercialisation des plants des arbres locaux. Cas de quatre pépinières rurales au Cameroun.

71. Les unités de transformation des produits forestiers non ligneux alimentaires au Cameroun. Diagnostic technique et stratégie de développement Honoré Tabuna et Ingratia Kayitavu.

72. Les exportateurs camerounais de safou (Dacryodes edulis) sur le marché sous régional et international. Profil, fonctionnement et stratégies de développement.

73. Impact of the Southeast Asian Network for Agroforestry Education (SEANAFE) on agroforestry education capacity.

74. Setting landscape conservation targets and promoting them through compatible land use in the Philippines.

75. Review of methods for researching multistrata systems.

76. Study on economic viability of Jatropha curcas L. plantations in Northern Tanzania assessing farmers' prospects via cost-benefit analysis

77. Cooperation in Agroforestry between Ministry of Forestry of Indonesia and International Center for Research in Agroforestry

78. "China's bioenergy future. an analysis through the Lens if Yunnan Province

79. Land tenure and agricultural productivity in Africa: A comparative analysis of the economics literature and recent policy strategies and reforms

80. Boundary organizations, objects and agents: linking knowledge with action in agroforestry watersheds

81. Reducing emissions from deforestation and forest degradation (REDD) in Indonesia: options and challenges for fair and efficient payment distribution mechanisms

\section{9}

82. Mainstreaming climate change into agricultural education: challenges and perspectives

83. Challenging conventional mindsets and disconnects in conservation: the emerging role of ecoagriculture in Kenya's landscape mosaics

84. Lesson learned RATA garut dan bengkunat: suatu upaya membedah kebijakan pelepasan kawasan hutan dan redistribusi tanah bekas kawasan hutan

85. The emergence of forest land redistribution in Indonesia

86. Commercial opportunities for fruit in Malawi

87. Status of fruit production processing and marketing in Malawi

88. Fraud in tree science

89. Trees on farm: analysis of global extent and geographical patterns of agroforestry

90. The springs of Nyando: water, social organization and livelihoods in Western Kenya

91. Building capacity toward region-wide curriculum and teaching materials development in agroforestry education in Southeast Asia

92. Overview of biomass energy technology in rural Yunnan (Chinese - English abstract)

93. A pro-growth pathway for reducing net $\mathrm{GHG}$ emissions in China

94. Analysis of local livelihoods from past to present in the central Kalimantan Ex-Mega Rice Project area

95. Constraints and options to enhancing production of high quality feeds in dairy production in Kenya, Uganda and Rwanda

\section{0}

96. Agroforestry education in the Philippines: status report from the Southeast Asian Network for Agroforestry Education (SEANAFE)

97. Economic viability of Jatropha curcas L. plantations in Northern Tanzania- assessing farmers' prospects via cost-benefit analysis.

98. Hot spot of emission and confusion: land tenure insecurity, contested policies and competing claims in the central Kalimantan Ex-Mega Rice Project area

99. Agroforestry competences and human resources needs in the Philippines 
100. CES/COS/CIS paradigms for compensation and rewards to enhance environmental Services

101. Case study approach to region-wide curriculum and teaching materials development in agroforestry education in Southeast Asia

102. Stewardship agreement to reduce emissions from deforestation and degradation (REDD): Lubuk Beringin's Hutan Desa as the first village forest in Indonesia

103. Landscape dynamics over time and space from ecological perspective

104. Komoditisasi atau koinvestasi jasa lingkungan: skema imbal jasa lingkungan program peduli sungai di DAS Way Besai, Lampung, Indonesia

105. Improving smallholders' rubber quality in Lubuk Beringin, Bungo district, Jambi province, Indonesia: an initial analysis of the financial and social benefits

106. Rapid Carbon Stock Appraisal (RACSA) in Kalahan, Nueva Vizcaya, Philippines

107. Tree domestication by ICRAF and partners in the Peruvian Amazon: lessons learned and future prospects in the domain of the Amazon Initiative eco-regional program

108. Memorias del Taller Nacional: "Iniciativas para Reducir la Deforestación en la region Andino Amazónica”, 09 de Abril del 2010. Proyecto REALU Peru

109. Percepciones sobre la Equidad y Eficiencia en la cadena de valor de REDD en Perú - Reporte de Talleres en Ucayali, San Martín y Loreto, 2009. Proyecto REALU-Perú.

110. Reducción de emisiones de todos los Usos del Suelo. Reporte del Proyecto REALU Perú Fase 1

111. Programa Alternativas a la Tumba-y-Quema (ASB) en el Perú. Informe Resumen y Síntesis de la Fase II. 2da. versión revisada

112. Estudio de las cadenas de abastecimiento de germoplasma forestal en la amazonía Boliviana

113. Biodiesel in the Amazon

114. Estudio de mercado de semillas forestales en la amazonía Colombiana

115. Estudio de las cadenas de abastecimiento de germoplasma forestal en Ecuador

116. How can systems thinking, social capital and social network analysis help programs achieve impact at scale?

117. Energy policies, forests and local communities in the Ucayali Region, Peruvian Amazon

118. NTFPs as a Source of Livelihood Diversification for Local Communities in the Batang Toru Orangutan Conservation Program

119. Studi Biodiversitas: Apakah agroforestry mampu mengkonservasi keanekaragaman hayati di DAS Konto?

120. Estimasi Karbon Tersimpan di Lahan-lahan Pertanian di DAS Konto, Jawa Timur

121. Implementasi Kaji Cepat Hidrologi (RHA) di Hulu DAS Brantas, Jawa Timur.

122. Kaji Cepat Hidrologi di Daerah Aliran Sungai Krueng Peusangan, NAD,Sumatra

123. A Study of Rapid Hydrological Appraisal in the Krueng Peusangan Watershed, NAD, Sumatra.

\section{1}

124. An Assessment of farm timber value chains in Mt Kenya area, Kenya

125. A Comparative financial analysis of current land use systems and implications for the adoption of improved agroforestry in the East Usambaras, Tanzania

126. Agricultural monitoring and evaluation systems

127. Challenges and opportunities for collaborative landscape governance in the East Usambara Mountains, Tanzania

128. Transforming Knowledge to Enhance Integrated Natural Resource Management Research, Development and Advocacy in the Highlands of Eastern Africa

129. Carbon-forestry projects in the Philippines: potential and challenges The Mt Kitanglad Range forest-carbon development

130. Carbon forestry projects in the Philippines: potential and challenges. The Arakan Forest Corridor forest-carbon project

131. Carbon-forestry projects in the Philippines: potential and challenges. The Laguna Lake Development Authority's forest-carbon development project

132. Carbon-forestry projects in the Philippines: potential and challenges. The Quirino forest-carbon development project in Sierra Madre Biodiversity Corridor

133. Carbon-forestry projects in the Philippines: potential and challenges. The Ikalahan ancestral domain forest-carbon development 
134. The Importance of Local Traditional Institutions in the Management of Natural Resources in the Highlands of Eastern Africa

135. Socio-economic assessment of irrigation pilot projects in Rwanda

136. Performance of three rambutan varieties(Nephelium lappaceum L.) on various nursery media

137. Climate change adaptation and social protection in agroforestry systems: enhancing adaptive capacity and minimizing risk of drought in Zambia and Honduras

138. Does value chain development contribute to rural poverty reduction? Evidence of asset building by smallholder coffee producers in Nicaragua

139. Potential for biofuel feedstock in Kenya

140. Impact of fertilizer trees on maize production and food security in six districts of Malawi.

\section{2}

141. Fortalecimiento de capacidades para la gestión del Santuario Nacional Pampa Hermosa: Construyendo las bases para un manejo adaptativo para el desarrollo local. Memorias del Proyect

142. Understanding rural institutional strengthening: A cross-level policy and institutional framework for sustainable development in Kenya

143. Climate change vulnerability of agroforestry

144. Rapid assesment of the inner Niger delta of Mali

145. Designing an incentive program to reduce on-farm deforestationin the East Usambara Mountains, Tanzania

146. Extent of adoption of conservation agriculture and agroforestry in Africa: the case of Tanzania, Kenya, Ghana, and Zambia

147. Policy incentives for scaling up conservation agriculture with trees in Africa: the case of Tanzania, Kenya, Ghana and Zambia

148. Commoditized or co-invested environmental services? Rewards for environmental services scheme: River Care program Way Besai watershed, Lampung, Indonesia.

149. Assessment of the headwaters of the Blue Nile in Ethiopia.

150. Assessment of the uThukela Watershed, Kwazaulu.

151. Assessment of the Oum Zessar Watershed of Tunisia.

152. Assessment of the Ruwenzori Mountains in Uganda.

153. History of agroforestry research and development in Viet Nam. Analysis of research opportunities and gaps 
The World Agroforestry Centre is an autonomous, non-profit research organization whose vision is a rural transformation in the developing world where smallholder households strategically increase their use of trees in agricultural landscapes to improve their food security, nutrition, income, health, shelter, energy resources and environmental sustainability. The Centre generates science-base knowledge about the diverse role that trees play in agricultural landscapes, and uses its research to advance policies and practices that benefit the poor and the environment.

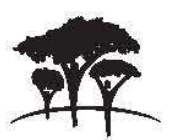

United Nations Avenue, Gigiri • PO Box 30677 • Nairobi, $00100 \cdot$ Kenya Telephone: +254207224000 or via USA +16508336645 Fax: +254207224001 or via USA +1 6508336646 Southeast Asia Regional Program - Sindang Barang, Bogor 16115 PO Box 161 Bogor 16001, Indonesia

Ph: +62 2518625415 - Fax: +62 2518625416

www.worldagroforestry.org/sea 